\title{
Strukturalne i programowe reformy polskiej oświaty w latach 1998-2017 na lamach tygodnika „Polityka”
}

\begin{abstract}
Structural and curriculum reforms in Polish education in 1998-2017 in the Polityka weekly

A radical reform of the education system, one of the pillars of the four major reforms of Jerzy Buzek's government, followed by a reform of the core curriculum by Minister Katarzyna Hall, and finally a controversial reform by Anna Zalewska under which some middle-level schools in operation since 1999 are being shut down are events covered in numerous publications, among them in leading opinion weeklies in Poland.

One of such weeklies is "Polityka," published continuously since 1957, where dozens of articles on education and reforms have been published over the last 20 years. The article is a concise analysis of the texts published in "Polityka", the issues raised and the authors' attitudes to the changes introduced in the subsequent years to the Polish education system.
\end{abstract}

Keywords: reforms of education, education, history of the Polish press

Gruntowna reforma systemu oświaty, stanowiąca jeden z filarów czterech wielkich reform rządu Jerzego Buzka, późniejsza o dekadę reforma podstawy programowej minister Katarzyny Hall, czy wreszcie budząca duże kontrowersje reforma systemu oświaty Anny Zalewskiej, na mocy której funkcjonujące od 1999 r. gimnazja są obecnie wygaszane - wszystkie te wydarzenia znalazły odzwierciedlenie w licznych publikacjach, pojawiających się m.in. na łamach wiodących tygodników opinii w Polsce. Ponieważ kwestie oświaty budzą żywe zainteresowanie znacznej części społeczeństwa, warto przyjrzeć się, jak wspomniane wyżej zagadnienia omawiano i komentowano w artykułach publikowanych na stronach „Polityki”, jednego z najpopularniejszych polskich tygodników ${ }^{1}$

\footnotetext{
1 W styczniu 2018 roku „Polityka” zajmowała drugą po „Gościu Niedzielnym” pozycję wśród najlepiej sprzedających się tygodników, https://www.wirtualnemedia.pl/artykul/sprzedaz-tygodnikow-opinii-w-styczniu2018-roku [dostęp: 25.06.2018]. Szerzej zob.: W. Władyka, „Polityka” i jej ludzie, Warszawa 2007.
} 
Przełomowy w najnowszych dziejach Polski rok 1989 nie przyniósł radykalnych zmian systemowych w oświacie. Przez kolejną dekadę funkcjonował dwuszczeblowy system kształcenia ogólnego, oparty na 8-letniej szkole podstawowej i 4-letnim liceum. Taki kształt polska szkoła zyskała na mocy uchwalonej w 1961 r. Ustawy o rozwoju systemu oświaty $i$ wychowania, wprowadzającej w pełni świecką organizację procesu kształcenia oraz wydłużającej obowiązek szkolny do 17 . roku życia ${ }^{2}$. Co prawda w latach 70. XX w. podjęto jeszcze próby wprowadzenia, wzorowanych na systemie radzieckim, tzw. dziesięciolatek ${ }^{3}$, jednak narastający kryzys gospodarczy i związane z nim trudności finansowe oraz problemy kadrowe i opór społeczny sprawiły, że w 1982 r. odstąpiono od tego pomysłu ${ }^{4}$.

U schyłku lat 90. minionego stulecia coraz wyraźniej słychać było postulaty różnych partii i środowisk, głoszących potrzebę przeprowadzenia zasadniczych zmian w polskim szkolnictwie. Głosy takie pojawiały się również na łamach „Polityki”. Na potrzeby niniejszego opracowania poddano analizie artykuły opublikowane w tym tygodniku w latach 1998-2017. Cezura początkowa wiąże się z wprowadzeniem reformy ustroju szkolnego, a więc gruntowną zmianą strukturalną i programową przeprowadzoną przez ministra Mirosława Handkego. W jej wyniku od 1 września 1999 roku w Polsce zaczęły funkcjonować 6-letnie szkoły podstawowe, 3-letnie gimnazja, a także 3-letnie licea profilowane i szkoły zawodowe ${ }^{5}$.

Na łamach tygodnika „Polityka” minister Handke gościł już w pierwszym styczniowym numerze z 1998 r., zapowiadając wstępnie planowane zmiany - m.in. nowy kształt egzaminu dojrzałości, egzamin po szkole podstawowej oraz obowiązkową maturę z matematyki ${ }^{6}$. Również w styczniu Handke ogłosił główne założenia reformy podczas spotkania z kuratorami i rektorami wyższych uczelni w Poznaniu. Poza omówieniem zmian w strukturze szkolnictwa, minister zapowiedział również wprowadzenie egzaminów po każdym cyklu kształcenia, które kwalifikować mają odpowiednio do szkoły ponadgimnazjalnej lub na studia. Ich przygotowanie i organizacja miały znaleźć się w gestii niezależnych państwowych komisji egzaminacyjnych - centralnej i lokalnych. Ważnym novum była również decyzja o wprowadzeniu sześciostopniowej ścieżki rozwoju zawodowego nauczycieli (stażysta, kontraktowy, nauczyciel, specjalista, dyplomowany

${ }^{2}$ Ustawa z dnia 15 lipca 1961 r. o rozwoju systemu oświaty $i$ wychowania, Dziennik Ustaw [dalej: Dz.U.] 1961, nr 32, poz. 160. Zob. też: M. Pęcherski, M. Świątek, Organizacja oświaty w Polsce w latach 1917-1969. Podstawowe akty prawne, Warszawa 1972, s. 81-90, 254-266; M. Krajewski, Historia wychowania i myśli pedagogicznej, Płock 2006, s. 244 i n.

${ }^{3}$ Uchwata Sejmu Polskiej Rzeczypospolitej Ludowej z dnia 13 października 1973 r. w sprawie systemu edukacji narodowej, Monitor Polski [dalej: M.P.] 1973, nr 44, poz. 260.

${ }^{4}$ M. Krajewski, op. cit., s. 248-249.

${ }^{5}$ Ustawa z dnia 25 lipca 1998 r. o zmianie ustawy o systemie oświaty, Dz.U. 1998, nr 117, poz. 759; Ustawa z dnia 8 stycznia 1999 r. Przepisy wprowadzajace reformę ustroju szkolnego, Dz.U. 1999, nr 12, poz. 96.

${ }^{6}$ Wystarczy nie przeszkadzać. Rozmowa z prof. dr. hab. Mirosławem Handke, ministrem edukacji narodowej, „Polityka” 1998, nr 1, s. 24-25. 
i profesor oświaty ${ }^{7}$ ). Wszystkie te założenia czytelnikom „Polityki” przybliżyła Ewa Nowakowska. W artykule Bryk szkolny, podkreślając potrzebę dokonania zmian i krytykując dotychczasowy encyklopedyczny sposób nauczania, Nowakowska zwróciła uwagę na pewien istotny problem polskiej polityki oświatowej: Jako kraj moglibyśmy aspirować do światowego mistrzostwa $w$ dziedzinie nie zrealizowanych pomysłów na nowoczesna oświatę. Niemal co drugi z czterdziestu jeden powojennych ministrów wychodził z jakimś projektem reformy, co czwarty zaczynat go wdrażać, ale w większości przypadków nastepca miat inny pomyst i rozpoczynat wtasna reformę. [...] Wiedziemy prym $w$ reformach totalnych i ogłaszanych z góry: bez pilotażu w skali lokalnej i bez analizy efektów pracy poprzedników ${ }^{8}$.

W kolejnych tygodniach na łamach „Polityki” pojawiło się kilka artykułów, w których m.in. omawiano kwestie planowanych zmian w egzaminie maturalnym (sylabusy, obowiązkowa matura z matematyki, kodowanie prac, egzaminatorzy zewnętrzni) ${ }^{9}$, koncepcję wprowadzenia przez rząd tzw. bonów edukacyjnych ${ }^{10}$ oraz postulowano konieczność wymiany kadr, wykształconych w większości w realiach minionego ustroju, oraz opracowania nowych metod i form kształcenia nauczycieli ${ }^{11}$. Bardzo szybko pojawiły się również artykuły krytyczne wobec zapowiadanej testowej formy egzaminów. Zofia Kłakówna, analizując testy z języka polskiego przygotowywane w Wałbrzychu przez Lokalny Ośrodek Badań Kompetencji Ucznia, stwierdziła dobitnie: Sposób egzaminowania wyznacza sposób uczenia do egzaminu. [...] Tego rodzaju testy pozoruja zmiany w szkole. [...] Testy sa nastawione na reprodukowanie faktografii (encyklopedyzm w najgorszym wydaniu). Sprawdzają znajomość przypadkowych faktów, zupetnie oderwanych od jakiegokolwiek kontekstu ${ }^{12}$.

Problem ten na łamach pisma powrócił w 2002 r., kiedy to pierwszy rocznik gimnazjalistów przystąpił do pisania egzaminu, mającego stanowić jeden z istotnych elementów uwzględnianych podczas rekrutacji do szkoły średniej. W tym samym roku niemal 7 tysięcy licealistów zdecydowało się na pisane matury w nowej formule. W opublikowanym przy tej okazji artykule Chrzest testów, jego autorzy zwrócili uwagę na jeszcze inną kwestię - uczniowie uzdolnieni, oczytani, myślący oryginalnie i nieszablonowo

\footnotetext{
7 Ostatecznie w rozporządzeniu ministerialnym uwzględniono cztery stopnie awansu zawodowego - stażysta, kontraktowy, mianowany i dyplomowany: Rozporządzenie Ministra Edukacji Narodowej z dnia 3 sierpnia 2000 r. w sprawie uzyskiwania stopni awansu zawodowego przez nauczycieli, Dz.U. 2000, nr 70, poz. 825. Od 2008 roku nadawany jest również honorowy tytuł profesora oświaty: Rozporządzenie Ministra Edukacji Narodowej z dnia 4 września 2008 r. w sprawie Kapituly do Spraw Profesorów Oświaty, Dz.U. 2008, nr 163, poz. 1017 .

${ }^{8}$ E. Nowakowska, Bryk szkolny, „Polityka” 1998, nr 6, s. 16-17.

9 K. Sułek, Nadciagaja sylabusy, „Polityka” 1998, nr 20, s. 18.

${ }^{10}$ Król bon. Rozmowa z Jerzym Millerem, podsekretarzem stanu w Ministerstwie Finansów, „Polityka” 1998, nr 20, s. 87-89.

11 W. Kulerski, Klasy strachu, „Polityka” 1998, nr 22, s. 20-22.

12 Z. A. Kłakówna, Kogel-mogel na głowie, „Polityka” 1998, nr 17, s. 80.
} 
mogą mieć problem ze zdaniem egzaminu testowego, arkuszowi bowiem towarzyszy klucz, z którym wszystkie odpowiedzi muszą być zgodne. Nieprzeciętny uczeń może udzielić odpowiedzi, których klucz nie uwzględnia i w efekcie egzaminu nie zdać lub otrzymać wynik zdecydowanie nieodpowiadający faktycznemu poziomowi jego wiedzy i umiejętności ${ }^{13}$.

W ciągu kolejnych miesięcy poprzedzających inaugurację roku szkolnego w nowej strukturze, na łamach „Polityki” ukazało się kilka artykułów Ewy Nowakowskiej, w których autorka zwracała uwagę na różnorodne kwestie związane z reformą. W tekście Szkoła: instrukcja obsługi raz jeszcze przybliżyła czytelnikom główne założenia planowanych zmian - nauczanie blokowe, a nie przedmiotowe w szkole podstawowej, wzorowane na reformie jędrzejewiczowskiej z 1932 r. gimnazja, ścieżki międzyprzedmiotowe, czy nowe stopnie awansu zawodowego nauczycieli. Warte podkreślenia są jednak uwagi, które autorka określiła mianem „katalogu wątpliwości”. Wśród nich na pierwszym miejscu wymienia obowiązek szkolny od 7., a nie 6. roku życia, co stanowi tendencję odwrotną od europejskiej, oraz rozciągnięcie nauczania początkowego na sześć lat. Minusem reformy było również, zdaniem Nowakowskiej, wprowadzenie tylko jednego języka obcego i to dopiero od IV klasy szkoły podstawowej, brak etyki jako alternatywy dla uczniów, którzy nie chcą uczęszczać na lekcje religii, przewidywany ogromny przyrost oświatowej biurokracji, związany z tworzeniem nowej sieci szkół, oraz brak działań zmierzających do odbudowania rangi zawodu nauczyciela ${ }^{14}$.

O konieczności poprawy wizerunku zawodu nauczyciela w odbiorze społecznym, przekonania pedagogów do reformy i potrzebie zdecydowanego wzrostu wynagrodzeń w oświacie Ewa Nowakowska pisała wielokrotnie ${ }^{15}$, jednak w cytowanym artykule zwróciła uwagę na inny, choć zaakcentowany już wcześniej problem: Na początku nowa szkoła będzie musiała zadowolić się stara kadra - sfrustrowana i sceptyczna wobec zmian. Blisko 70 proc. nauczycieli to ludzie z dhugim i bardzo dlugim stażem, widać wyraźnie luke pokoleniowa, która reformatorzy będa musieli jak najszybciej wypetnić16.

Po podpisaniu przez prezydenta Aleksandra Kwaśniewskiego ustawy o zmianie ustroju szkolnego, na łamach tygodnika zaczynają pojawiać się artykuły dotyczące trudności, z jakimi musiały zmierzyć się gminy - faktyczni wykonawcy ministerialnych rozporządzeń. Większość problemów odnosi się do kwestii finansowych. W założeniu reforma miała stanowić podstawę faktycznego wyrównywania szans edukacyjnych i lepszego

13 A. Niezgoda, E. Nowakowska, M. Czubaj, Chrzest testów, „Polityka” 2002, nr 20, s. 16-20. Problem tzw. testomanii powracał na łamy tygodnika również w kolejnych latach. Zob. m.in.: A. Niezgoda, Zmowa testowa, „Polityka” 2004, nr 49, s. 90-91; J. Podgórska, Ucz się pod klucz, „Polityka” 2011, nr 19, s. 14-16; eadem, Mniej niż zero, „Polityka” 2011, nr 21, s. 28; J. Żakowski, Odkuwanie głów, „Polityka” 2013, nr 20, s. $16-18$.

14 E. Nowakowska, Szkoła: instrukcja obstugi, „Polityka” 1998, nr 23, s. 3-8.

15 E. Nowakowska, Przyjęcie bez kucharza, „Polityka” 1998, nr 36, s. 32-34; eadem, Gra w karte, „Polityka” 1998, nr 43, s. 80-82; taż, Gimbusem do przodu, „Polityka” 1999, nr 5, s. 76-77.

${ }^{16}$ E. Nowakowski, Szkoła: instrukcja..., s. 6. 
startu młodzieży wiejskiej. W każdym gminnym gimnazjum powinna zostać stworzona pracownia komputerowa i odpowiednia sala gimnastyczna, a nauczycieli szczególnie pożądanych przedmiotów (m.in. języki obce, informatyka) miały zachęcić do przyjazdu na wieś specjalne dodatki do pensji ${ }^{17}$. Tymczasem gminna rzeczywistość wyglądała zupełnie inaczej. Lokalne społeczności często nie godziły się z decyzjami dotyczącymi zamykania szkół podstawowych w poszczególnych miejscowościach lub lokalizacją planowanych gimnazjów ${ }^{18}$, a same gminy niejednokrotnie nie były w stanie finansowo sprostać czekającym je zadaniom. Kwestię niezbędnych remontów i doposażenia pracowni potęgowały przewidywane tzw. ciche koszty reformy - etat dla kierowcy gimbusa, paliwo i koszt spłaty kredytu na zakup gimbusa, jeśli ministerstwo nie zdąży takich pojazdów zapewnić ${ }^{19}$.

Osobny problem stanowił chaos na rynku podręcznikowym. Nauczyciele zyskali swobodę w wyborze programu nauczania i podręcznika, co zapoczątkowało prawdziwą walkę o klienta. Jednak ze względu na bardzo późne opublikowanie podstaw programowych, a co za tym idzie konkretnych programów, wydawcy mieli zaledwie kilka miesięcy na przygotowanie podręczników ${ }^{20}$. Problem podręczników i ich jakości na łamy „Polityki" powracał jeszcze kilkakrotnie. Ogrom oferty wydawniczej w zasadzie uniemożliwiał nauczycielowi rzetelne poznanie wszystkich dostępnych na rynku publikacji, a ich zawartość pozostawiała często wiele do życzenia. W wielu podręcznikach pojawiały się błędy merytoryczne i gramatyczne, a większość z nich powstała jako nowsza, nieco graficznie poprawiona wersja starych książek, przeładowanych informacjami, niedostosowanych do możliwości intelektualnych przeciętnego ucznia ${ }^{21}$. Jeszcze w $2002 \mathrm{r}$. Piotr Sarzyński informował, że na wszystkich etapach kształcenia, od przedszkola do szkoły ponadgimnazjalnej, można korzystać łącznie z 818 programów i 1458 podręczników. Wobec tych ostatnich wysuwał znane już zarzuty - błędy językowe i merytoryczne, ogromną objętość (są to często liczące kilkaset stron „cegły”) i wciąż obecny encyklopedyzm podręcznikowej narracji ${ }^{22}$.

Dość ciekawy obraz reformy wyłania się z artykułów ukazujących się w pierwszym roku funkcjonowania gimnazjów. Już we wrześniu 1999 r. Ewa Nowakowska informowała, że gimbusy trafiły do zaledwie 190 spośród 1600 uprawnionych do tego gmin. Powodowało to oczywiście duże utrudnienia w dowozie dzieci i rosnące niezadowolenie rodziców. Przytoczyła również wyniki badań Instytutu Spraw Publicznych, z których

17 E. Nowakowska, Odchudzanie marzeń, „Polityka” 1999, nr 9, s. 76.

18 P. Pytlakowski, Dorzuci się wygódkę, „Polityka” 1999, nr 12, s. 28-29; R. Socha, Szkoła białych owiec, „Polityka” 1999, nr 15, s. 26-27.

19 P. Pytlakowski, Kryptonim Gimbus, „Polityka” 1999, nr 14, s. 30-32.

20 E. Nowakowska, Kleks i spółka, „Polityka” 1999, nr 35, s. 61-62.

21 B. Mikołajewska, Aby na listę, „Polityka” 2000, nr 37, s. 20-22; E. Nowakowska, Dziecko pod cegłami, „Polityka” 2000, nr 38, s. 81-82.

22 P. Sarzyński, Podręczniki do tablicy!, „Polityka” 2002, nr 35, s. 3-9. 
wynikało, że wśród nauczycieli było wówczas 89\% zwolenników reformowania szkolnictwa jako takiego, jednak zwolenników wprowadzonej reformy ministra Handkego już tylko $22 \%$ (w tym 5\% zwolenników bez zastrzeżeń) ${ }^{23}$.

W kolejnym numerze pisma, ta sama autorka informowała o dramatycznych brakach pieniędzy w kasach gmin na realizację założeń reformy. Samorządy skarżyły się, że 60\% ich budżetów pochłania oświata. O skali zjawiska może również świadczyć fakt, że planowano utworzyć 3,5 tys. gimnazjów, a ostatecznie powstało ich nieco ponad 5 tys. ${ }^{24}$ W artykule tym Ewa Nowakowska po raz pierwszy zwróciła uwagę na zjawisko, które już wkrótce będzie jednym z głównych argumentów przeciwników gimnazjów: [...] trafia tu dzieci $w$ wieku dojrzewania, który jest wychowawczo najtrudniejszy: pełen niepokoju, buntu i poszukiwań własnej, niezależnej drogi. Nauczyciele gimnazjalni, obok realizacji nowego programu, będa musieli sprostać większym wyzwaniom natury psychologicznej i spolecznej ${ }^{25}$.

Ta sama autorka w kolejnych artykułach przedstawiła dalekie od założeń realia funkcjonowania gimnazjów, których we wrześniu 2000 r. było 4834 (2270 miejskich i 2564 wiejskich). Według danych zawartych w tekście, ponad 68\% szkół tego typu dzieliło budynki i kadrę ze szkołami podstawowymi, tworząc sztuczne 9-klasowe twory, działające w warunkach znacznie gorszych niż dotychczasowe. Blisko 300 szkół, to tzw. wirtualne gimnazja, które nie miały swojej siedziby, a poszczególne klasy gimnazjalne rozrzucone były w różnych szkołach podstawowych. Nieco ponad 200 szkół tworzyło zespoły z liceami (zwykle renomowanymi), zaś tylko niewiele ponad tysiąc gimnazjów stanowiło samodzielne jednostki. Dodać przy tym należy, że w dużych miastach były to prawdziwe kombinaty, liczące po 20 i więcej równoległych oddziałów (rekord - 28 oddziałów). W tej sytuacji nie sposób uniknąć trudności wychowawczych ${ }^{26}$.

Artykuły dotyczące przemocy w gimnazjach, panującej tam fali, pojawiających się problemach z wczesną inicjacją seksualną, ciążami, używkami i agresją, także wobec nauczycieli, angażowaniem firm ochroniarskich, montowaniem monitoringu etc., pojawiały się na łamach „Polityki” wielokrotnie ${ }^{27}$. Po kilku latach funkcjonowania tego typu

23 E. Nowakowska, Belfer w reformach, „Polityka” 1999, nr 36, s. 60-62. Problem braku gimbusów jeszcze u schyłku 2002 r., a więc w trzecim roku wdrażania reformy, sygnalizował Igor T. Miecik. Jak wynika z jego artykułu, do tego czasu gimbusy trafiły zaledwie do co czwartej gminy, a „obietnica ministra „Gimbus w każdej gminie" w bardzo szybkim tempie zmieniała swój kształt: nie w każdej gminie, ale w każdej wiejskiej, w połowie gmin, a właściwie w co piątej, nie gimbus, lecz kredyt na gimbus i tak dalej”: I. T. Miecik, Gimbustyka, „Polityka” 2002, nr 44, s. 28.

24 E. Nowakowska, Sześć dodać trzy, „Polityka” 1999, nr 37, s. 72-73.

25 Ibidem, s. 72.

${ }^{26}$ E. Nowakowska, Idzie goly do szkoty, „Polityka” 2000, nr 36, s. 72-73; zob. też: eadem, Ósma w kacie, „Polityka” 1999, nr 42, s. 80-81; S. Mizerski, Nowa szkoła, „Polityka” 2001, nr 3, s. 3-9; Uczeń ma prawo płakać. Rozmowa z Mirosława Kątna, psychologiem, o szkolnych stresach i zagrożeniach, „Polityka” 2001, nr 35, s. 66-67.

27 A. Niezgoda, Szkoła bez klasy, „Polityka” 2005, nr 38, s. 34-36; M. Bunda, Panny na wygnaniu, „Polityka” 2005, nr 45, s. 6-12; E. Winnicka, Wojna szkolna, „Polityka” 2006, nr 22, s. 6-13; M. Bunda, Trzech na 
szkół należało więc uczciwie spojrzeć na ten aspekt reformy, z którym wciąż sobie nie radzono: Oto człowiek 13-letni: już nie dziecko, jeszcze nie dorosty. Zbuntowany, choć jeszcze nie wie, w imię czego. Rozchwiany emocjonalnie. Bez pomystu na dorosłość. Nie chce być słaby, ale nie wie, jak być silnym. I wtedy właśnie reforma wyrywa go z zastanego środowiska, rzucając do walki o pozycje w nowym gimnazjalnym stadzie. Aby sie przebić, sięga po najprostsza manifestację dorosłości: używki, przemoc ${ }^{28}$.

Ważne w tym kontekście są jednak również słowa prof. Zbigniewa Izdebskiego, pedagoga i seksuologa, który stwierdził: Gimnazjum jako koncepcja to strzat w dziesiatkę. Ten segment szkolny wpisuje się w osobny etap rozwoju człowieka. Skoszarowanie pod jednym dachem jest tu wskazane. Ale to etap tak delikatny, że w gimnazjum nauczyciel bardziej powinien być wychowawca. Tyle że nikt nauczyciela tego nie uczy we właściwy sposób ${ }^{29}$.

Problem właściwego, zgodnego z nowymi potrzebami kształcenia kadr pedagogicznych na łamach „Polityki” postulowano wielokrotnie. Niestety na początku XXI w. sytuacja kształtowała się niekorzystnie. W jednym z numerów tygodnika analizie poddano raport NIK-u, stworzony po kontroli 14 wyższych uczelni. Wynikało z niego, że zdecydowana większość studentów kierunków nauczycielskich (50-70\%) kształciła się w trybie zaocznym. Plany dydaktyczne takich studiów rażąco odbiegały od wytycznych Rady Głównej Szkolnictwa Wyższego, dotyczących minimalnych wymagań. Studenci zaoczni odbywali zaledwie 1/3 godzin zajęć realizowanych przez studentów stacjonarnych, a kadrę na takich studiach rekrutowano zwykle spośród asystentów i adiunktów. Wiele do życzenia pozostawiały również warunki lokalowe oraz wyposażenie bibliotek. W raporcie zwrócono także uwagę na niedociągnięcia ministerstwa - brak opracowanych standardów kształcenia i przygotowania pedagogicznego oraz choćby projektu rozporządzenia w sprawie wymaganych kwalifikacji $\mathrm{i}^{30}$.

W kwietniu 2000 r. Ewa Nowakowska przybliżyła czytelnikom „Polityki” projekt reformy szkolnictwa ponadgimnazjalnego, sankcjonujący tworzenie 3-letnich liceów profilowanych i 2-letnich szkół zawodowych. Wobec braku techników, ich funkcje przejąć miały wspomniane wyżej licea, w których proponowano tworzenie pięciu rodzajów profili: akademickie, techniczno-technologiczne, rolniczo-środowiskowe, społeczno-usługowe oraz kulturalno-artystyczne. Zwieńczeniem edukacji na tym poziomie miała być matura z języka polskiego, matematyki, języka obcego oraz jednego przedmiotu wybranego przez ucznia. Wynik tego egzaminu stanowić miał podstawę rekrutacji do szkół wyższych. Taki kształt szkolnictwa ponadgimnazjalnego, zgodnie z założeniami ministra

Marka, „Polityka” 2006, nr 49, s. 92-95; M. Kołodziejczyk, Gnojki, „Polityka” 2012, nr 43, s. 26-28; E. Turlej, Dziewczynki po biuście, „Polityka” 2014, nr 10, s. 26-29; Szkoły przetrwania. Rozmowa z Małgorzata Jonczy-Adamska, psycholożka i pedagożka, o tym, kto i dlaczego jest dziś napiętnowany i prześladowany w szkole, „Polityka” 2015, nr 17, s. 27-29.

28 A. Niezgoda, Szkoła bez klasy..., s. 36.

29 Ibidem.

${ }^{30}$ E. Nowakowska, Pani od niczego, „Polityka” 2001, nr 33, s. 72-73. 
Handkego, miał sprzyjać szerszemu dostępowi młodzieży do edukacji i zwiększeniu z niespełna $30 \%$ do $80 \%$ liczby uczniów legitymujących się zdaną maturą ${ }^{31}$.

Osobnym problemem, na który uwagę zwróciła autorka artykułu, pozostawała kwestia przewidywanych zwolnień nauczycieli, spośród bowiem 170 tys. pedagogów pracujących w szkołach ponadgimnazjalnych, aż 90 tys. zatrudnionych było w tym czasie $\mathrm{w}$ technikach ${ }^{32}$. Niezadowolenie w środowisku nauczycielskim potęgowało również wejście w życie znowelizowanej Karty Nauczyciela, na mocy której obowiązywać zaczęły nowe stopnie awansu zawodowego ${ }^{33}$. Wielu pedagogów na tej zmianie straciło, a rozgoryczenie potęgował brak zapowiadanych przez rząd i wynikających z wyżej wspomnianej nowelizacji podwyżek ${ }^{34}$.

Bardzo wiele obaw i wątpliwości, które przebijały z łamów „Polityki”, budził przełomowy rok 2002, w którym po raz pierwszy polscy uczniowie mieli się zmierzyć z nową formą egzaminu gimnazjalnego oraz z nową maturą. Tę ostatnią jako obowiązkową dla wszystkich abiturientów, minister Krystyna Łybacka przesunęła ostatecznie na rok 2005, przywracając równocześnie do życia technika ${ }^{35}$. Pozostawał jednak problem rekrutacji do szkół średnich oraz na wyższe uczelnie, które często nie chciały, zwłaszcza na atrakcyjnych i obleganych kierunkach, uznawać wyniku matury za jedyne kryterium uwzględniane podczas naboru. Również w szkołach średnich wynik egzaminu gimnazjalnego stanowić miał jedynie 50\% punktów możliwych do uzyskania w ramach rekrutacji. Resztę stanowiły oceny $\mathrm{z}$ wybranych przedmiotów oraz punkty przyznawane za dodatkowe osiągnięcia ${ }^{36}$.

Analiza wyników egzaminu z 2002 r. przyniosła dość nieoczekiwane spostrzeżenia i wnioski, do których doszedł zespół naukowców z Instytutu Geografii i Przestrzennego Zagospodarowania PAN. Czytelnikom „Polityki” zaprezentowano je w artykule pod znamiennym tytułem Polska dzielnicowa ${ }^{37}$. Cóż bowiem ujawniły przeprowadzone po raz pierwszy egzaminy po szkole podstawowej i gimnazjum? Otóż mapa wyników, sporzą-

31 E. Nowakowska, Niebieskie migdaty?, „Polityka” 2000, nr 27, s. 67.

32 Ibidem.

33 Ustawa z dnia 18 lutego 2000 r. o zmianie ustawy - Karta Nauczyciela oraz o zmianie niektórych innych ustaw, Dz.U. 2000, nr 19, poz. 239.

34 Zob. m.in.: E. Nowakowska, Szlaban na karte, „Polityka” 2000, nr 23, s. 92; eadem, Ktoś nie umie liczyć, „Polityka” 2000, nr 27, s. 67; eadem, Podwyżki przez obniżki, „Polityka” 2000, nr 41, s. 76-77; eadem, Więcej, czyli mniej, „Polityka” 2000, nr 44, s. 88.

35 E. Nowakowska, Próba niskiej próby, „Polityka” 2001, nr 39, s. 104-106; eadem, Lekcja niewychowawcza, „Polityka” 2001, nr 43, s. 3-8; eadem, Kontrreformacja, „Polityka” 2001, nr 44, s. 18.

${ }^{36}$ A. Niezgoda, Wygimbus, „Polityka” 2001, nr 16, s. 78-79; E. Nowakowska, Szkoła improwizacji, „Polityka” 2001, nr 25, s. 79-80; A. Hucuł, Wolność, równość, nadgorliwość, „Polityka” 2002, nr 27, s. 89-90. Jeszcze w 2005 r., kiedy już wszyscy absolwenci szkół średnich zdawali nową maturę, tygodnik „Polityka” informował, że na wielu uczelniach egzaminy wstępne zastąpione zostały tzw. sprawdzianami predyspozycji. Na Uniwersytecie Warszawskim, taki sprawdzian przewidywano na 34 spośród 76 kierunków: M. Czubaj, Egzamin nieufności, „Polityka” 2005, nr 7, s. 36-37.

37 E. Nowakowska, Podzial dzielnicowy, „Polityka” 2002, nr 45, s. 89-91. 
dzona przez wyżej wspomniany zespół badaczy, wyraźnie wykazała ogromne zróżnicowanie regionalne. Szczególnie ostre różnice zaznaczyły się pomiędzy ziemiami zachodnimi i północnymi, które wypadły najgorzej, a resztą kraju. Ewidentna jest również przepaść pomiędzy wynikami miast i wsi. Na wysoki wynik egzaminu wpływ miała bowiem zarówno sytuacja gospodarcza w regionie i wynikające z niej ogólne warunki życia oraz dostęp do edukacji, ale także szeroko rozumiane dziedzictwo historyczne i kulturowe. $\mathrm{W}$ analizie podkreślono, że wyniki egzaminów były tym lepsze, im większe lokalne wydatki na oświatę w przeliczeniu na jednego ucznia. Nie bez znaczenia pozostawała również liczba nauczycieli na stu uczniów - im liczba ta była większa, tym wynik był lepszy. Jak zatem łatwo się domyślić, najwyższe wyniki egzaminów odnotowano w dużych miastach, w których sieć szkolna jest różnorodna, a oferta edukacyjna bogata. Najgorsze zaś odnotowano na terenach popegeerowskich, w których jest wysokie bezrobocie, ale też niskie wykształcenie i aspiracje rodziców ${ }^{38}$.

Wynik egzaminu z 2002 r. uświadomił z całą mocą, że utworzone trzy lata wcześniej gimnazja dość szybko stały się szkołami, które nie tylko nie muszą niwelować różnic edukacyjnych, ale mogą je wręcz pogłębiać. Autorzy „Polityki” zwracali uwagę na takie niebezpieczeństwo już wcześniej - pisano m.in. o szufladkowaniu uczniów i tworzeniu klas elitarnych ${ }^{39}$ oraz o niepokojącym spadku odsetka uczących się na wsiach nastolatków, z których co piąty kończy edukację na szkole podstawowej ${ }^{40}$. Swoistym podsumowaniem takiego obrazu polskiej szkoły po reformie mogą stać się słowa Mariusza Czubaja: [...] gimnazja okazały się najmniej udanym tworem reformy. Potwierdzajacym, że dobre nawet założenia obracaja się przeciw ich twórcom. Gimnazja miaty wyrównywać różnice między uczniami, dawać szanse dzieciom ze społecznie upośledzonych środowisk. Tymczasem ten próg okazuje się $w$ catym procesie edukacji najbardziej selekcyjny $i$, miast wyrównywania szans, pogłębia nierówności ważące na całym dalszym życiu ${ }^{41}$.

W kolejnych latach publicyści „Polityki” zwracali uwagę czytelników na powracające problemy związane $\mathrm{z}$ wysokimi cenami podręczników ${ }^{42}$, nieskuteczną edukacją na wszystkich szczeblach kształcenia, kreującą ogromny rynek korepetycji oraz różnego rodzaju gotowców ${ }^{43}$, rosnącą liczbą szkół wyższych, w których jakość nauczania pozo-

38 Ibidem.

39 A. Niezgoda, Nowa walka klasowa, „Polityka” 2001, nr 40, s. 32-33.

${ }^{40}$ A. Niezgoda, Marzenia szyte na miarę, „Polityka” 2004, nr 14, s. 90-92. W późniejszych latach problem gimnazjów elitarnych, obserwowanej w szkołach swoistej segregacji i wszechobecnych rankingów powracał jeszcze na łamy tygodnika. Zob. m.in.: A. Sowa, Elitarni, „Polityka” 2006, nr 1, s. 74-76; E. Winnicka, Dzieci i dzieci-śmieci, „Polityka” 2008, nr 26, s. 89-91.

${ }^{41}$ M. Czubaj, 13-16-19, „Polityka” 2005, nr 15, s. 30.

42 M. Czubaj, Ala nie ma kasy, „Polityka” 2006, nr 4, s. 34-36.

${ }^{43}$ M. Czubaj, Szkoła w oślej ławce, „Polityka” 2004, nr 20, s. 3-10; idem, Sąd Ostateczny niedrogo, „Polityka” 2005, nr 10, s. 94-96; idem, Matury tortury, „Polityka” 2005, nr 20, s. 24-26; A. Sowa, Zakorkowani, „Polityka” 2006, nr 10, s. 40-42; B. Mikołajewska, Pokolenie kopiuj-wklej, „Polityka” 2010, nr 21, s. 34-39; eadem, Plaga plagiatów, „Polityka” 2010, nr 43, s. 38-43; J. Cieśla, Ostatni rozdział, „Polityka” 2012, nr 12, s. 92-93. 
stawiała często wiele do życzenia ${ }^{44}$, a także wciąż obecną w szkole agresją. Ten ostatni problem nabrał szczególnego znaczenia, gdy minister Roman Giertych ogłosił w 2006 r. program „Zero tolerancji dla przemocy w szkole”. I choć na łamach tygodnika nie negowano potrzeby podjęcia radykalnych działań, które pozwoliłyby naprawić istniejący stan rzeczy, to jednak poczynania ministra nie zyskały większego poparcia ${ }^{45}$. Krytykując posunięcia Giertycha, powoływano się m.in. na wyniki badań prof. Janusza Czapińskiego, który dowodził, że zwiększenie restrykcyjności przyniosło skutek odwrotny od ministerialnych założeń. O ile bowiem ogólny poziom zachowań agresywnych pozostawał od lat raczej niezmienny, o tyle po wprowadzeniu radykalnych rozwiązań zdecydowanie wzrósł poziom agresji na linii nauczyciele-uczniowie. Tylko w ciągu jednego roku wdrażania programu „Zero tolerancji” (2006-2007) liczba nauczycieli przyznających się do tego, że byli w szkole prowokowani do wybuchu gniewu wzrosła z $14 \%$ do $19 \%$, przyznających, że uczniowie ignorują ich polecenia - z 20\% do $29 \%$, zaś z 3\% do 5\% wzrosła liczba nauczycieli, którzy zostali przez uczniów zmuszeni do zrobienia czegoś, czego ci żądali. Była oczywiście także druga strona tego medalu - w ciągu roku z $6 \%$ do $8 \%$ wzrosła liczba uczniów przyznających, że padli ofiarą przemocy ze strony nauczyciela oraz z 16\% do $20 \%$ twierdzących, że nauczyciel używał wobec nich obraźliwych słów ${ }^{46}$.

Rok 2007 przyniósł wybory parlamentarne, które zmieniły układ sił rządzących w Polsce. Nową minister Edukacji Narodowej została Katarzyna Hall ${ }^{47}$, która na początku 2008 r. zapowiedziała na łamach „Polityki”: Pracujemy nad poważna reforma programowa, która ma być wdrożona od 1 września 2009 r. Obniżamy wiek szkolny do 6 lat, co ma sprzyjać wyrównywaniu szans edukacyjnych. [...] Za pót roku powstanie podstawa programowa kształcenia ogólnego na 12 lat, do końca liceum. Będzie wdrażana w cyklu sześcioletnim, poczynając od I klasy szkoły podstawowej i od I gimnazjum. Nowe programy będą wchodzić sukcesywnie ${ }^{48}$.

\footnotetext{
${ }^{4}$ W jednym z artykułów Mariusz Czubaj przytacza interesujące dane związane z liczbą szkół wyższych, których w roku akademickim 1990/1991 było w Polsce 112, a już dekadę później 344. Wyraźnie wzrosła również liczba szkół niepaństwowych z 6 w 1990 do 250 w 2000 r.: M. Czubaj, Studia wyższe: dziś promocja!, „Polityka” 2005, nr 25, s. 4-12. Zob. też: E. Wilk, Przekrój gejzeru, „Polityka” 2009, nr 26, s. 16-18.

45 Zob. m.in.: E. Winnicka, Wojna szkolna, „Polityka” 2006, nr 22, s. 6-13.

${ }^{46}$ Rzecz o szczuciu. Z prof. Januszem Czapińskim o niespodziewanych konsekwencjach poczynań ministra edukacji Romana Giertycha w polskich szkołach i o tym, jak wybrnać z tego bigosu - rozmawia Jacek Żakowski, „Polityka” 2007, nr 10, s. 6-12. Na łamach „Polityki” omawiano także ministerialne założenia i szkolną rzeczywistość związane z wprowadzaniem tzw. stroju jednolitego, czyli szkolnych mundurków, których pomysłodawcą był minister Roman Giertych: R. Socha, Każdemu po mundurku, „Polityka” 2007, nr 15, s. 90-93; A. Zagner, Coś zwane mundurkiem, „Polityka” 2007, nr 38, s. 27-29.

${ }^{47}$ Sylwetka nowej minister oraz jej droga zawodowa w: R. Socha, Pani poukładana, „Polityka” 2007, nr 47, s. 32-34.

48 Odmawiam majstrowania. Rozmowa z Katarzyna Hall, minister edukacji narodowej, „Polityka” 2008, nr 5, s. 25 .
} 
Niestety dość rewolucyjna i kontrowersyjna ${ }^{49}$ reforma podstawy programowej została niemal całkowicie przesłonięta przez dyskusję dotyczącą kwestii obniżenia obowiązku szkolnego do 6. roku życia. W niektórych artykułach pojawiały się co prawda pozytywne oceny planowanych zmian - m.in. obowiązkowej edukacji przedszkolnej, programowego łączenia kolejnych etapów edukacji, czy zmodyfikowanej listy lektur z języka polskiego $^{50}$, jednak największe zainteresowanie publicystów budziła kwestia sześciolatków w szkole. Wiązało się to oczywiście z szerokim ruchem sprzeciwu społecznego, na czele którego stanęło małżeństwo Tomasza i Karoliny Elbanowskich. Również oni mieli możliwość zaprezentowania swojego stanowiska na łamach „Polityki”. Czytelnicy tygodnika mogli wówczas przeczytać m.in.: Nie jesteśmy przeciwnikami wcześniejszej nauki dzieci - chodzi nam tylko o warunki tej edukacji. Żeby była przyjazna, nie wystarczy przesunać tawke i położyć dywan ${ }^{51}$.

Koncepcja ministerialna w tej kwestii znalazła jednak gorliwych obrońców wśród publicystów „Polityki”. Jacek Żakowski podkreślał na przykład demograficzny wymóg przesunięcia o rok obowiązku szkolnego - edukację rozpocząć miał właśnie najniższy rocznik niżu, co miało gwarantować przyjęcie wszystkich dzieci do szkół: 6- i 7-latków. Jeśli tak się nie stanie, prorokował Żakowski, w kilkuletniej perspektywie czeka nas klęska w naborze na studia, a później ogromny problem na rynku pracy ${ }^{52}$. W artykule możemy również przeczytać: Wszystkie reformy, które się w Polsce udały, robione były na kolanie. Inaczej nie umiemy. Tym razem na komfort rezygnacji z reformy ani nawet na jej odsunięcie po prostu nas nie stać. Gdybyśmy się cofnęli, sześciolatki, które w przysztym roku maja iść do szkoły, zapłaca za to więcej niż za niedociagnięcia reformy robionej $w$ pośpiechu ${ }^{53}$.

Skala społecznego oporu sprawiła jednak, że ostateczną decyzję o obniżeniu obowiązku szkolnego odkładano przez kilka najbliższych lat, powołując się na niedostateczne przygotowanie szkół lub wprowadzając dobrowolność w tym zakresie i powierzając rozstrzygnięcie kwestii gotowości szkolnej dziecka w ręce rodziców (i fachowców z poradni psychologiczno-pedagogicznych $)^{54}$.

\footnotetext{
49 Zob. m.in. dyskusję na temat reformy podstawy programowej historii, jaka toczyła się na łamach „Wiadomości Historycznych”: G. Okła, Ewolucja koncepcji edukacji historycznej - w kierunku efektywności ksztatcenia, „Wiadomości Historyczne” 2009, nr 3, s. 16-19; G. Chomicki, Rozmyślania nad reforma, czyli poprawianie ideału, „Wiadomości Historyczne” 2009, nr 4, s. 39-47; J. Choińska-Mika, Rozważania nad reforma - kilka uwag polemicznych, „Wiadomości Historyczne” 2009, nr 5, s. 32-35.

50 E. Wilk, Dramat obowiązkowy, „Polityka” 2008, nr 18, s. 22; J. Podgórska, Cenzurka dla szkoty, „Polityka" 2008, nr 25, s. 33-37.

${ }^{51}$ Szkoda dzieci. Rozmowa z Karolina i Tomaszem Elbanowskimi, inicjatorami rodzicielskiego protestu przeciw posłaniu sześciolatków do szkót, „Polityka” 2008, nr 40, s. 26-28.

52 J. Żakowski, Sześć, siedem, pięć, „Polityka” 2008, nr 39, s. 16-18.

53 Ibidem, s. 18.

${ }^{5}$ J. Cieśla, Ślad czarnej kredki, „Polityka” 2008, nr 42, s. 34-35; E. Winnicka, Pani na dywanie, „Polityka” 2011, nr 12, s. 30-31; M. Bunda, J. Cieśla, J. Podgórska, E. Wilk, Rok z czterema niewiadomymi, „Polity-
} 
Na łamach „Polityki” zasadniczy element reformy, a więc tzw. nowa podstawa programowa, dość dokładnie omówiony został tylko raz - w artykule Janiny Podgórskiej, dotyczącym zmian w podstawie z historii. Warto jednak podkreślić, że tekst ten ukazał się dopiero w 2012 r., a więc w momencie, gdy pierwszy rocznik uczący się zgodnie z nowymi wytycznymi kończył właśnie gimnazjum i miał rozpocząć edukację w szkołach wyższego szczebla. W swoim artykule Podgórska, krytykując protesty przeciwników nowej podstawy, przybliżyła czytelnikom najważniejsze, jej zdaniem, wady wcześniej obowiązującej. Na szczególną uwagę zasługuje kwestia trzykrotnego powtarzania całego kursu historii na poszczególnych etapach kształcenia. Skutkowało to zwykle dość dobrą znajomością przez uczniów najstarszych epok z dziejów ludzkości, ze szkodą dla historii najnowszej. Tę bowiem omawiano zawsze w ostatnich miesiącach edukacji w ostatniej klasie, co z różnych względów (egzaminy, zielone szkoły etc.) nie sprzyjało pełnej realizacji materiału. W spiralnym układzie treści i wprowadzeniu spójności programowej III i IV etapu edukacyjnego (gimnazjum i szkoła ponadgimnazjalna), autorka widziała szansę na zmianę tego stanu rzeczy ${ }^{55}$. Nowa podstawa programowa miała również stanowić alternatywę dla dotychczasowego, archaicznego kształcenia. W artykule czytamy m.in.: Przekaz, że patriotyzm polega na nieustannym umieraniu za ojczyzne $z$ rack wroga $i$ martyrologii, wzmacniaja lekcje historii $w$ starym stylu, czyli prezentacja faktów w kluczu polityczno-militarnym. [...] przekaz edukacyjny powinien być bardziej spójny ze wspótczesnym światem, dać narzędzia, które pozwola zrozumieć rzeczywistość, odnaleźć się $w$ wielokulturowej społeczności. Historia potraktowana nie jako zamknięta narracja, o tym ,jak to naprawdę było”, ale szukanie w przeszłości genezy współczesnych zjawisk, może $w$ tym tylko pomóc ${ }^{56}$.

W kolejnych latach tematyka oświatowa na łamach „Polityki” gościła nieco rzadziej, choć oczywiście stale powracał wątek 6-latków (zob. przypis 54). Coraz bardziej krytycznie poruszano też kwestię obecności religii w szkole, jej kosztów, liczby godzin szkolnej katechezy oraz planów wprowadzenia matury z religii ${ }^{57}$. Jacek Żakowski, jeden z bardziej popularnych publicystów tygodnika, dość ostro krytykował przeładowanie szkolnego materiału treściami zbyt szczegółowymi lub zupełnie niepotrzebnymi: [...] kiedy powstawała szkoła, jaka znamy, ludzkość nie znała szczepionek, elektronów, chromosomów, obu wojen światowych, kilku rewolucji, wszystkich noblowskich powieści, teorii względności, radia, telewizji, kultury masowej, nie mówiąc o Internecie. To wszystko przez póttora wieku chaotycznie dopisywano do programu szkoły, dodają jej lat, godzin i niespójnych erudycyjnych wymagańn ${ }^{58}$.

ka” 2012, nr 26, s. 28-30; E. Wilk, Wojna sześcioletnia, „Polityka” 2013, nr 17/18, s. 34-35; J. Cieśla, Maluchy się ratuja, „Polityka” 2013, nr 45, s. 26-28; E. Wilk, Mama ma kota, „Polityka” 2014, nr 18, s. 18-21.

55 J. Podgórska, Histeria, „Polityka” 2012, nr 14, s. 34-37.

56 Ibidem, s. 37

57 Zob. m.in.: J. Podgórska, Tańce z matura, „Polityka” 2012, nr 48, s. 14-15; eadem, Bo większość cho$d z i$, ,Polityka” 2013, nr 36, s. 8-10; eadem, Kateschiza, „Polityka” 2013, nr 37, s. 25-27.

58 J. Żakowski, Odkuwanie głów, „Polityka” 2013, nr 20, s. 17. 
Stopniowo zaczęła się również rysować dyskusja na temat przyszłości gimnazjów. Już w 2013 r. prof. Bogusław Śliwerski, komentując głosy polityków różnych opcji, wśród których wymienił nazwiska byłych szefów resortu edukacji - Krystyny Łybackiej, Romana Giertycha i Ryszarda Legutki, stwierdził wyraźnie, że likwidacja gimnazjów byłaby jedynie kolejnym politycznym happeningiem. Ich oczywistym minusem jest fakt, że stanowią jedyny wariant tego typu szkoły średniej, co jest ewenementem w skali całej Unii Europejskiej. Obok kształcenia ogólnego powinno bowiem funkcjonować równolegle kształcenie o charakterze politechnicznym i zawodowym, by umożliwić komfort edukacji także uczniom o mniejszych aspiracjach lub możliwościach intelektualnych. Śliwerski, jako uznany pedagog, postulował zatem uzupełnienie struktury edukacyjnej w Polsce o szkoły średnie I stopnia o charakterze techniczno-praktycznym ${ }^{59}$.

W wyborczym roku 2015 temat likwidacji gimnazjów powrócił m.in. jako element programu Prawa i Sprawiedliwości (PiS). Również w „Polityce” Marcin Kołodziejczyk poruszył tę kwestię w artykule Czas postrzyżyn, przytaczając wyniki badania przeprowadzonego jeszcze w 2013 r. przez Instytut Badań Homo Homini. Wynikało z niego, że $60 \%$ Polaków chce likwidacji gimnazjów, a niemal $50 \%$ twierdzi, że szkoły te uczą źle ${ }^{60}$. Wśród argumentów pojawiały się powtarzane już wielokrotnie wątki dotyczące przeładowanych programów, trudnego wieku uczęszczającej do gimnazjów młodzieży oraz selekcji, która zastąpiła wyrównywanie szans. Kołodziejczyk podkreślił jednak, że reforma z 1999 r. jest wciąż reformą niedokończoną, o czym świadczą m.in. gimnazja ulokowane w jednych budynkach ze szkołami podstawowymi ${ }^{61}$.

W przededniu wyborów czytelnikom „Polityki” dość szczegółowo przybliżony został program PiS w kontekście postulowanych zmian w systemie edukacji - m.in. obowiązek szkolny od 7. roku życia, likwidacja gimnazjów, licencjatów i testowej formy egzaminów. Ewa Wilk, która analizy tej dokonała, przekonywała jednak, że opinia o gimnazjach jako siedlisku przemocy i patologii ma jedynie charakter utrwalonego w społeczeństwie stereotypu. Postulowała również: [...] polskiej edukacji najbardziej potrzebny jest chwilowy choćby spokój, czas na podleczenie ran po przejściach. Nie wszystko jest z nia w porządku, z kilku zaulków można by ja zgodnie wyprowadzić. [...] Warto to wszystko zrobić. Bez kontrrewolucji proponowanej przez PiS. Kontrrewolucji właśnie, bo system edukacji postulowany przez tę partię niepokojaco kojarzy się z peerelowskim, wyjąwszy oczywiście przeciwny cel ideowy ${ }^{62}$.

Informacja o stereotypowym postrzeganiu gimnazjów jako szkół, w których występuje problem agresji i przemocy, może zaskakiwać w kontekście licznych artykułów poświęconych tej kwestii na łamach samej „Polityki” (zob. przypis 27). Warto jednak podkreślić, że $\mathrm{w}$ kolejnych tekstach powoływano się na ustalenia specjalistów m.in.

\footnotetext{
59 B. Śliwerski, Precz z gimnazjami?, „Polityka” 2013, nr 35, s. 32-33.

${ }^{60}$ M. Kołodziejczyk, Czas postrzyżyn, „Polityka” 2015, nr 13, s. 32.

61 Ibidem, s. 32-34.

${ }^{62}$ E. Wilk, Klucz do szkoły, „Polityka” 2015, nr 36, s. 23.
} 
z Instytutu Badań Edukacyjnych dowodzące, że większą skalę zachowań agresywnych odnotowuje się obecnie w wyższych klasach szkoły podstawowej niż w gimnazjach czy liceach ${ }^{63}$.

Po wygranych przez PiS wyborach i oficjalnym ogłoszeniu planowanych zmian, na łamach „Polityki” pojawiło się wiele artykułów, w których rzeczowo odnoszono się do negatywnych aspektów funkcjonowania gimnazjów, jednak przestrzegano przed reformą forsowaną przez partię rządzącą. I tak, Ewa Wilk, przybliżająca czytelnikom jej główne założenia, informowała o pierwszych oznakach sprzeciwu organizowanego w mediach społecznościowych $^{64}$, a była minister Katarzyna Hall, ostro krytykowała nowelizację ustawy o systemie oświaty, przegłosowaną w ostatnich dniach grudnia 2015 r., znoszącą obowiązek przedszkolny 5-latków i wprowadzającą obowiązek szkolny od 7. roku ży$\mathrm{cia}^{65}$. Minister Hall napisała: Przez ostatnie lata sprawa sześciolatka cały czas była polityczna. Teraz - z politycznych powodów - zawrócono system edukacji do dawnych czasów, bez szukania merytorycznych argumentów, zwiąanych z potrzebami rozwojowymi dzieci, ani prowadzenia konsultacji z eksperckimi środowiskami ${ }^{66}$.

Cenne uwagi do dyskusji nad sensownością likwidacji gimnazjów wniosła również psycholog - dr Małgorzata Wójcik, która w jednym z pierwszych numerów „Polityki” z 2016 r. przekonywała, że podział na szkołę podstawową i gimnazjum jest w pełni uzasadniony ze względu na cykl rozwojowy dziecka. Gimnazjum stanowi na tej drodze istotny punkt ku dorosłości, dający szansę na pozbycie się dotychczasowej etykiety oraz przyjęcie nowej roli społecznej. Likwidacja gimnazjów, zdaniem dr Wójcik, nie zlikwiduje problemów, które z nimi kojarzymy. Realne jest natomiast ryzyko, że powrócą one do podstawówki, być może w jeszcze większej skali ${ }^{67}$.

Wszelkie dyskusje dotyczące losów polskiej oświaty zostały jednak ucięte zaraz po zakończeniu roku szkolnego 2015/2016, gdy minister Anna Zalewska ogłosiła w Toruniu projekt reformy systemu edukacji. Joanna Cieśla, autorka opisującego to wydarzenie artykułu Zabawy szkoła, wybór miejsca (w Toruniu zainicjowano akcję „Ratujmy gimnazja") oraz termin (początek wakacji gwarantujący spokój w pokojach nauczycielskich) określiła, nie bez racji, jako arogancki gest wobec nauczycieli, samorzadowców, rodziców $i$ samych uczniów ${ }^{68}$. Poza ogólną charakterystyką wprowadzanych zmian: 8-klaso-

${ }^{63}$ Zob. m.in.: J. Cieśla, Zabawy szkoła, „Polityka” 2016, nr 28, s. 19-21; eadem, E. Bendyk, Co dalej z edukacją?, „Polityka” 2017, nr 10, s. 26-29.

${ }^{64}$ E. Wilk, Dostaniemy dobra szkote, ,Polityka” 2015, nr 47, s. 26-28.

${ }^{65}$ K. Hall, Cofanie w rozwoju, „Polityka” 2016, nr 4, s. 28-30. W jednym z artykułów Joanny Cieśli z tego okresu pojawia się informacja, że ustawa o systemie oświaty z 1991 roku przez 25 lat była nowelizowana ponad 70 razy, a więc średnio trzy razy w roku: J. Cieśla, Rok przed wyrokiem, „Polityka” 2016, nr 36, s. $14-16$.

${ }^{66}$ K. Hall, Cofanie w rozwoju, „Polityka” 2016, nr 4, s. 30.

${ }^{67}$ Królowie i ofiary. Z dr Małgorzata Wójcik, psycholożka, badaczka zachowań nastolatków, o przemocy rówieśniczej, o tym, dlaczego nie warto likwidować gimnazjów oraz co powinni wiedzieć rodzice, gdy dziecko domaga się markowych butów, „Polityka” 2016, nr 6, s. 32-34.

68 J. Cieśla, Zabawy szkoła, ,Polityka” 2016, nr 28, s. 19. 
wej szkoły podstawowej, 4-letniego liceum oraz 5-letniego technikum lub dwustopniowej szkoły branżowej, Zalewska podkreślała zasadność reformy, powołując się na wyniki ogólnopolskiej debaty (50 w siedzibie MEN, 17 wojewódzkich i ponad 200 w całym kraju $)^{69}$. Niestety, po wystąpieniu pani minister pozostało bardzo wiele niewiadomych i jeszcze więcej zastrzeżeń, do których autorzy „Polityki” powracali także w kolejnych numerach tygodnika. Pisano m.in. o pokrzywdzonych uczniach przyszłej klasy VII, którzy, po pierwsze, trafią w sam środek czteroletniego cyklu kształcenia, a więc niektórych przedmiotów uczyć się będą niejako od połowy, a po drugie, podczas rekrutacji do szkoły średniej staną w szranki ze znacznie lepiej przygotowanymi absolwentami gimnazjów jako rocznik zdublowany. Przy okazji pozbawiony jednego roku nauczania języka obcego. Krytykowano chaos towarzyszący planowaniu i tworzeniu nowej sieci szkół przez samorządy oraz kwestię efektywności i zaangażowania w pracę nauczycieli, którzy będą musieli uzupełniać pensum, pracując w kilku szkołach. Zdecydowanie negatywnie oceniono również pierwsze zaprezentowane podstawy programowe jako zbyt przeładowane, ale także pozbawione korelacji między omawianymi zagadnieniami w obrębie poszczególnych przedmiotów oraz między nimi ${ }^{70}$.

W kwestii likwidowanych gimnazjów warto oddać jeszcze głos prof. Mikołajowi Herbstowi, który stwierdził: [...] likwidując gimnazja, ministerstwo, ot tak, mimochodem, decyduje o skróceniu o rok ogólnego kształcenia, wspólnego dla całej kohorty uczniów. To chyba jedyny w cywilizowanym świecie przypadek reformy ograniczajacej dostęp do edukacji $i^{71}$.

Słowa te są znamienne. Wprowadzenie do polskiej szkoły tzw. dobrej zmiany na łamach tygodnika „Polityka” zostało potraktowane raczej jako oksymoron. Wbrew ministerialnym zapowiedziom tysiące nauczycieli straciło pracę lub ma ograniczone etaty. Strajk nauczycieli, mimo bardzo niewielkiej skali (ok. 30\%), wynikającej z braku jedności w środowisku, spowodował w wielu szkołach inspekcje kuratoryjnych wizytatorów. Media, w tym także „Politykę”, obiegły informacje na temat postępowań dyscyplinarnych wobec pedagogów, którzy nie wpisują się w obowiązujący obecnie wizerunek szkoły - sprawy nauczycielek, które wzięły udział w tzw. czarnym proteście w Zabrzu, czy też nauczyciela z Żagania, który na swoim facebookowym profilu umieścił odcinek „Ucha prezesa"72.

69 Ibidem, s. 19-21.

70 J. Cieśla, Bunt szkół, „Polityka” 2017, nr 4, s. 24-26; eadem, E. Bendyk, Co dalej..., s. 26-29; K. Zdanowicz, Szkoła przetrwania, „Polityka” 2017, nr 25, s. 12-15; Po dzwonku. Rozmowa z prof. Stanisławem Dylakiem o dobrej szkole, do której nam coraz dalej, o polskiej szkole systemowego deformowania oraz o szkole marzeń, „Polityka” 2017, nr 36, s. 26-28; J. Cieśla, Trudna lekcja, „Polityka” 2017, nr 36, s. 29-31.

${ }^{71}$ Szkolne błędy. Dr hab. Mikołaj Herbst, ekspert zarządzania oświata, o tym, jak sobie poradzić z nadciagajaca reforma edukacji, „Polityka” 2016, nr 46, s. 34.

72 J. Cieśla, Szkoła niskich nalotów, „Polityka” 2017, nr 16, s. 26-28; K. Zdanowicz, Szkoła przetrwania, „Polityka” 2017, nr 25, s. 12-15. 
Czy to jest dobra zmiana? Na to pytanie będziemy w stanie odpowiedzieć dopiero za kilka lat. Chyba, że w międzyczasie dotknie nas kolejna reforma...

\section{Bibliografia}

\section{Źródła normatywne i drukowane}

Pęcherski M., Świątek M., Organizacja oświaty w Polsce w latach 1917-1969. Podstawowe akty prawne, Warszawa 1972.

Rozporządzenie Ministra Edukacji Narodowej z dnia 3 sierpnia 2000 r. w sprawie uzyskiwania stopni awansu zawodowego przez nauczycieli, Dziennik Ustaw 2000, nr 70, poz. 825.

Rozporządzenie Ministra Edukacji Narodowej z dnia 4 września 2008 r. w sprawie Kapituly do Spraw Profesorów Oświaty, Dziennik Ustaw 2008, nr 163, poz. 1017.

Uchwała Sejmu Polskiej Rzeczypospolitej Ludowej z dnia 13 października 1973 r. w sprawie systemu edukacji narodowej, Monitor Polski 1973, nr 44, poz. 260.

Ustawa z dnia 15 lipca 1961 r. o rozwoju systemu oświaty $i$ wychowania, Dziennik Ustaw 1961, nr 32, poz. 160 .

Ustawa z dnia 18 lutego 2000 r. o zmianie ustawy - Karta Nauczyciela oraz o zmianie niektórych innych ustaw, Dziennik Ustaw 2000, nr 19, poz. 239.

Ustawa z dnia 25 lipca 1998 r. o zmianie ustawy o systemie oświaty, Dziennik Ustaw 1998, nr 117, poz. 759.

Ustawa z dnia 8 stycznia 1999 r. Przepisy wprowadzające reformę ustroju szkolnego, Dziennik Ustaw 1999, nr 12, poz. 96.

\section{Opracowania}

Krajewski M., Historia wychowania i myśli pedagogicznej, Płock 2006.

Władyka W., ,Polityka” i jej ludzie, Warszawa 2007.

\section{Artykuły}

Bunda M., Cieśla J., Podgórska J., Wilk E., Rok z czterema niewiadomymi, „Polityka” 2012, nr 26, s. $28-30$.

Bunda M., Panny na wygnaniu, „Polityka” 2005, nr 45, s. 6-12.

Bunda M., Trzech na Marka, „Polityka” 2006, nr 49, s. 92-95.

Choińska-Mika J., Rozważania nad reforma - kilka uwag polemicznych, „Wiadomości Historyczne" 2009, nr 5, s. 32-35.

Chomicki G., Rozmyślania nad reforma, czyli poprawianie ideału, „Wiadomości Historyczne” 2009, nr 4, s. 39-47.

Cieśla J., Bendyk E., Co dalej z edukacją?, „Polityka” 2017, nr 10, s. 26-29.

Cieśla J., Bunt szkót, „Polityka” 2017, nr 4, s. 24-26.

Cieśla J., Maluchy się ratuja, „Polityka” 2013, nr 45, s. 26-28. 
Cieśla J., Ostatni rozdziat, „Polityka” 2012, nr 12, s. 92-93.

Cieśla J., Rok przed wyrokiem, „Polityka” 2016, nr 36, s. 14-16.

Cieśla J., Szkoła niskich nalotów, „Polityka” 2017, nr 16, s. 26-28.

Cieśla J., Ślad czarnej kredki, „Polityka” 2008, nr 42, s. 34-35.

Cieśla J., Trudna lekcja, „Polityka” 2017, nr 36, s. 29-31.

Cieśla J., Zabawy szkoła, „Polityka” 2016, nr 28, s. 19-21.

Czubaj M., 13-16-19, „Polityka” 2005, nr 15, s. 28-37.

Czubaj M., Ala nie ma kasy, „Polityka” 2006, nr 4, s. 34-36.

Czubaj M., Egzamin nieufności, „Polityka” 2005, nr 7, s. 36-37.

Czubaj M., Matury tortury, „Polityka” 2005, nr 20, s. 24-26.

Czubaj M., Sad Ostateczny niedrogo, „Polityka” 2005, nr 10, s. 94-96.

Czubaj M., Studia wyższe: dziś promocja!, „Polityka” 2005, nr 25, s. 4-12.

Czubaj M., Szkoła w oślej ławce, „Polityka” 2004, nr 20, s. 3-10.

Hall K., Cofanie w rozwoju, „Polityka” 2016, nr 4, s. 28-30.

Hucuł A., Wolność, równość, nadgorliwość, „Polityka” 2002, nr 27, s. 89-90.

Kłakówna Z. A., Kogel-mogel na głowie, „Polityka” 1998, nr 17, s. 80-81.

Kołodziejczyk M., Czas postrzyżyn, „Polityka” 2015, nr 13, s. 32-34.

Kołodziejczyk M., Gnojki, „Polityka” 2012, nr 43, s. 26-28.

Król bon. Rozmowa z Jerzym Millerem, podsekretarzem stanu w Ministerstwie Finansów, „Polityka" 1998, nr 20, s. 87-89.

Królowie i ofiary. Z dr Małgorzata Wójcik, psycholożka, badaczka zachowań nastolatków, o przemocy rówieśniczej, o tym, dlaczego nie warto likwidować gimnazjów oraz co powinni wiedzieć rodzice, gdy dziecko domaga się markowych butów, „Polityka” 2016, nr 6, s. 32-34.

Kulerski W., Klasy strachu, „Polityka” 1998, nr 22, s. 20-22.

Miecik I. T., Gimbustyka, „Polityka” 2002, nr 44, s. 28-30.

Mikołajewska B., Aby na listę, „Polityka” 2000, nr 37, s. 20-22.

Mikołajewska B., Plaga plagiatów, „Polityka” 2010, nr 43, s. 38-43.

Mikołajewska B., Pokolenie kopiuj-wklej, „Polityka” 2010, nr 21, s. 34-39.

Mizerski S., Nowa szkoła, „Polityka” 2001, nr 3, s. 3-9.

Niezgoda A., Marzenia szyte na miare, „Polityka” 2004, nr 14, s. 90-92.

Niezgoda A., Nowa walka klasowa, „Polityka” 2001, nr 40, s. 32-33.

Niezgoda A., Nowakowska E., Czubaj M., Chrzest testów, „Polityka” 2002, nr 20, s. 16-20. Niezgoda A., Zmowa testowa, „Polityka” 2004, nr 49, s. 90-91.

Niezgoda A., Szkoła bez klasy, „Polityka” 2005, nr 38, s. 34-36.

Niezgoda A., Wygimbus, „Polityka” 2001, nr 16, s. 78-79.

Nowakowska E., Belfer w reformach, „Polityka” 1999, nr 36, s. 60-62.

Nowakowska E., Bryk szkolny, „Polityka” 1998, nr 6, s.16-17.

Nowakowska E., Dziecko pod cegłami, „Polityka” 2000, nr 38, s. 81-82.

Nowakowska E., Gimbusem do przodu, „Polityka” 1999, nr 5, s. 76-77.

Nowakowska E., Gra w karte, „Polityka” 1998, nr 43, s. 80-82.

Nowakowska E., Idzie goty do szkoty, „Polityka” 2000, nr 36, s. 72-73.

Nowakowska E., Kleks i spótka, „Polityka” 1999, nr 35, s. 61-62.

Nowakowska E., Kontrreformacja, „Polityka” 2001, nr 44, s. 18.

Nowakowska E., Ktoś nie umie liczyć, „Polityka” 2000, nr 27, s. 67.

Nowakowska E., Lekcja niewychowawcza, „Polityka” 2001, nr 43, s. 3-8.

Nowakowska E., Niebieskie migdały?, „Polityka” 2000, nr 17, s. 8.

Nowakowska E., Odchudzanie marzeń, „Polityka” 1999, nr 9, s. 76.

Nowakowska E., Ósma w kącie, „Polityka” 1999, nr 42, s. 80-81. 
Nowakowska E., Pani od niczego, „Polityka” 2001, nr 33, s. 72-73.

Nowakowska E., Podwyżki przez obnizkki, „Polityka” 2000, nr 41, s. 76-77.

Nowakowska E., Podziat dzielnicowy, „Polityka” 2002, nr 45, s. 89-91.

Nowakowska E., Próba niskiej próby, „Polityka” 2001, nr 39, s. 104-106.

Nowakowska E., Przyjęcie bez kucharza, „Polityka” 1998, nr 36, s. 32-34.

Nowakowska E., Sześć dodać trzy, „Polityka” 1999, nr 37, s. 72-73.

Nowakowska E., Szkoła improwizacji, „Polityka” 2001, nr 25, s. 79-80.

Nowakowska E., Szkoła: instrukcja obstugi, „Polityka” 1998, nr 23, s. 3-8.

Nowakowska E., Szlaban na kartę, „Polityka” 2000, nr 23, s. 92.

Nowakowska E., Więcej, czyli mniej, „Polityka” 2000, nr 44, s. 88.

Odmawiam majstrowania. Rozmowa z Katarzyna Hall, minister edukacji narodowej, „Polityka” 2008, nr 5, s. 24-26.

Okła G., Ewolucja koncepcji edukacji historycznej - w kierunku efektywności kształcenia, „Wiadomości Historyczne" 2009, nr 3, s. 16-19.

Po dzwonku. Rozmowa z prof. Stanisławem Dylakiem o dobrej szkole, do której nam coraz dalej, o polskiej szkole systemowego deformowania oraz o szkole marzeń, „Polityka” 2017, nr 36, s. $26-28$.

Podgórska J., Bo większość chodzi, „Polityka” 2013, nr 36, s. 8-10.

Podgórska J., Cenzurka dla szkoty, „Polityka” 2008, nr 25, s. 33-37.

Podgórska J., Histeria, „Polityka” 2012, nr 14, s. 34-37.

Podgórska J., Kateschiza, „Polityka” 2013, nr 37, s. 25-27.

Podgórska J., Mniej niż zero, „Polityka” 2011, nr 21, s. 28.

Podgórska J., Tańce z matura, „Polityka” 2012, nr 48, s. 14-15.

Podgórska J., Ucz się pod klucz, „Polityka” 2011, nr 19, s. 14-16.

Pytlakowski P., Dorzuci się wygódkę, „Polityka” 1999, nr 12, s. 28-29.

Pytlakowski P., Kryptonim Gimbus, „Polityka” 1999, nr 14, s. 30-32.

Rzecz o szczuciu. Z prof. Januszem Czapińskim o niespodziewanych konsekwencjach poczynań ministra edukacji Romana Giertycha w polskich szkołach i o tym, jak wybrnąć z tego bigosu - rozmawia Jacek Żakowski, „Polityka” 2007, nr 10, s. 6-12.

Sarzyński P., Podręczniki do tablicy!, „Polityka” 2002, nr 35, s. 3-9.

Socha R., Każdemu po mundurku, „Polityka” 2007, nr 15, s. 90-93.

Socha R., Pani pouktadana, „Polityka” 2007, nr 47, s. 32-34.

Socha R., Szkoła biatych owiec, „Polityka” 1999, nr 15, s. 26-27.

Sowa A., Elitarni, „Polityka” 2006, nr 1, s. 74-76.

Sowa A., Zakorkowani, „Polityka” 2006, nr 10, s. 40-42.

Sułek K., Nadciagaja sylabusy, „Polityka” 1998, nr 20, s. 18.

Szkoda dzieci. Rozmowa z Karolina i Tomaszem Elbanowskimi, inicjatorami rodzicielskiego protestu przeciw postaniu sześciolatków do szkót, „Polityka” 2008, nr 40, s. 26-28.

Szkolne błędy. Dr hab. Mikołaj Herbst, ekspert zarządzania oświata, o tym, jak sobie poradzić $z$ nadciagajaca reforma edukacji, „Polityka” 2016, nr 46, s. 33-35.

Szkoły przetrwania. Rozmowa z Matgorzata Jonczy-Adamska, psycholożka i pedagożka, o tym, kto i dlaczego jest dziś napiętnowany i przé́ladowany w szkole, „Polityka” 2015, nr 17, s. 27-29.

Śliwerski B., Precz z gimnazjami?, „Polityka” 2013, nr 35, s. 32-33.

Turlej E., Dziewczynki po biuście, „Polityka” 2014, nr 10, s. 26-29.

Uczeń ma prawo płakać. Rozmowa z Mirosława Kątna, psychologiem, o szkolnych stresach $i$ zagrożeniach, „Polityka” 2001, nr 35, s. 66-67.

Wilk E., Dostaniemy dobra szkote, „Polityka” 2015, nr 47, s. 26-28.

Wilk E., Dramat obowiazkowy, „Polityka” 2008, nr 18, s. 22. 
Wilk E., Klucz do szkoty, „Polityka” 2015, nr 36, s. 20-23.

Wilk E., Mama ma kota, „Polityka” 2014, nr 18, s. 18-21.

Wilk E., Przekrój gejzeru, „Polityka” 2009, nr 26, s. 16-18.

Wilk E., Wojna sześcioletnia, „Polityka” 2013, nr 17/18, s. 34-35.

Winnicka E., Dzieci i dzieci-śmieci, „Polityka” 2008, nr 26, s. 89-91.

Winnicka E., Pani na dywanie, „Polityka” 2011, nr 12, s. 30-31.

Winnicka E., Wojna szkolna, „Polityka” 2006, nr 22, s. 6-13.

Wystarczy nie przeszkadzać. Rozmowa z prof. dr. hab. Mirosławem Handke, ministrem edukacji narodowej, „Polityka” 1998, nr 1, s. 24-25.

Zagner A., Coś zwane mundurkiem, „Polityka” 2007, nr 38, s. 27-29.

Zdanowicz K., Szkola przetrwania, „Polityka” 2017, nr 25, s. 12-15.

Żakowski J., Odkuwanie głów, „Polityka” 2013, nr 20, s. 16-18.

Żakowski J., Sześć, siedem, pięć, „Polityka” 2008, nr 39, s. 16-18.

\section{Źródła internetowe}

https://www.wirtualnemedia.pl/artykul/sprzedaz-tygodnikow-opinii-w-styczniu-2018-roku 
